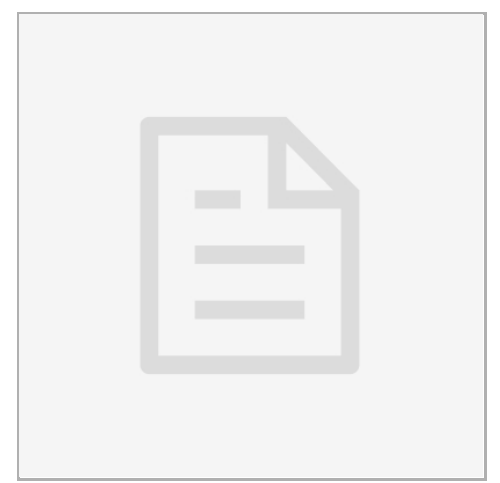

JUN 24, 2019

open ठAccess

DOI:

dx.doi.org/10.17504/protocol s.io.3f6gjre

Protocol Citation: Akila Wijerathna Yapa, Andrew F Bowerman, Diep R Ganguly 2019. RNA extractions from de-etiolated Arabidopsis seedlings using CTAB. protocols.io

https://dx.doi.org/10.17504/p rotocols.io.3f6gjre

License: This is an open access protocol distributed under the terms of the Creative Commons Attribution License, which permits unrestricted use, distribution, and reproduction in any medium, provided the original author and source are credited

Protocol status: Working We use this protocol in our group and it is working, though it will be continually developed.

Created: May 29, 2019

Last Modified: Jun 24, 2019

PROTOCOL integer ID: 23774

\section{(3) RNA extractions from de-etiolated Arabidopsis seedlings using CTAB}

\author{
Akila Wijerathna Yapa ${ }^{1}, \quad$ Andrew F Bowerman², \\ Diep R Ganguly ${ }^{3}$
} ${ }^{1}$ The Hebrew University of Jerusalem; ${ }^{2}$ The Australian National University;
${ }^{3}$ University of Pennsylvania

$$
\text { Pogson Group EBL_ANU }
$$

Diep R Ganguly

University of Pennsylvania, The Australian National Universi...

\section{ABSTRACT}

A CTAB based method for extracting RNA, which is particularly useful for tough tissues. This has been adapted from a protocol that was originally used for pine tree tissue, which is difficult due to the high concentrations of polysaccharides, phenolics, and RNase (Chang, S., Puryear, J. \& Cairney, J. Plant Mol Biol Rep (1993) 11: 113. https://doi.org/10.1007/BF02670468). The protocol described herein was an effective alternative to TRIzol based extractions for recovering RNA from juvenile deetiolated tissues.

\section{GUIDELINES}

Ensure that you use RNA friendly practices (e.g. clean surfaces with RNAesy or $80 \%$ ethanol, use RNAase-free filter tips, use DEPC-treated water for buffers, adjust RNA buffer $\mathrm{pH}$ to be slightly acidic [e.g. 6] in which RNA is more stable). 
Keywords: RNA, de-etiolated seedlings, Arabidopsis, Plant
MATERIALS

MATERIALS

88 Isoamylalcohol Contributed by users

88 Beta-mercaptoethanol Contributed by users

88 Chloroform Contributed by users

88 DEPC Contributed by users

88

Hexadecyltrimethylammonium bromide (CTAB) Sigma Aldrich Catalog \#H9151

$8880 \%$ Ethanol Contributed by users

88 Lithium chloride Sigma Aldrich Catalog \#793620

88 Polyvinylpyrrolidone K 30 Sigma Aldrich Catalog \#81420

\section{Extraction buffer}

1. $2 \% \mathrm{CTAB}$

2. $2 \%$ PVP K30

3. $100 \mathrm{mM}$ Tris-HCl (pH 8.0)

4. $25 \mathrm{mM}$ EDTA (pH 8.0)

5. $2 \mathrm{M} \mathrm{NaCl}$

6. Autoclave

7. $2 \% 2$-mercaptoethanol (add before use $=100 \mathrm{uL}$ per $5 \mathrm{~mL}$ buffer)

\section{SAFETY WARNINGS}

(1) Perform steps with 2-mercaptoethanol in a fume hood.

\section{BEFORE START INSTRUCTIONS}

Prepare extraction buffer (requires autoclaving) and lithium chloride solution before starting. You may consider filter-sterilizing these to be extra cautious.

$1 \quad$ Harvest tissues into liquid nitrogen and grind (under liquid nitrogen) using mortar and pestle to obtain a fine powder. Ground tissue should be kept in safe-lock tubes in liquid nitrogen (or returned to $-80 \mathrm{C}$ storage) until all samples are processed. This step is critical for efficient extractions so take your time here.

2 Add $1 \mathrm{~mL}$ of prewarmed $\left(65^{\circ} \mathrm{C}\right)$ extraction buffer to each tube, mix well and incubate for $5 \mathrm{mins}$ at $65^{\circ} \mathrm{C}$ (can be longer if needed e.g. 10-15 mins) 
3 Add 200 ul of chloroform:IAA (24:1), mix well and spin @ 14,000 rcf for 10 mins. Remove upper aqueous phase to a new tube. Make sure not to disturb or pipette any material from the interface. Repeat chloroform:IAA step twice, being increasingly conservative when recovering the aqueous phase.

4 Add equal volume of $5 \mathrm{M} \mathrm{LiCl}$ to aqueous layer, mix well and incubate overnight @ $-20^{\circ} \mathrm{C}$.

5 Spin tubes@ 14,000 rcf for 20 mins @ $4^{\circ} \mathrm{C}$.

6 Remove supernatant with pipette, add $1 \mathrm{~mL} 80 \%$ ethanol and invert tube $10 \mathrm{X}$. Centrifuge @ 7,500 rcf for 5 minutes @ RT. Remove ethanol and repeat.

7 Remove as much ethanol as possible using a pipette. Air-dry tubes with lid open for $1 \mathrm{~min}$.

Resuspend in 30 - 50 ul (depending on expected concentration and purpose, e.g. we aim for $\sim 500$ $\mathrm{ng} / \mathrm{ul}$ ) DEPC-treated water or low EDTA TE buffer (0.1 mM EDTA, $10 \mathrm{mM}$ Tris base, pH 6.5).

8 Check quality of RNA e.g. visualize 50 ng RNA on a 1\% agarose gel or use BioAnalyser / LabChip GXII. 